\title{
Memories of My Father
}

\author{
Jonathan E.M. LINDBERG ${ }^{1}$ \\ Scientific Assistant, Integrative Physiology and Neuroscience, Washington State \\ University Pullman, WA. U.S.A.
}

Keywords. Donald A.B. Lindberg M.D., Lindberg family history

\section{The Farm}

In the 1960s, my father (Donald A.B. Lindberg M.D.) bought a 130-acre farm north of the mid-western town, Columbia, MO. It was on this farm that my brothers and I learned to swim, fish, ride horses, ice skate, shoot guns, and ultimately help dad finish a cabin by the lake. We came of age there. I learned skills from my father that have stuck with me and shaped who I am.

Fishing, ice skating, swimming, and guns were all cool until Dad got us horses. He spent time learning about horses and discovered a common fault when getting children into horses was to buy a Shetland Pony, which is bred for their small size but not necessarily for their disposition. I would learn many years later that my dad's decisions were well researched, and the results, in this case, were three wonderful, gentle, wellmannered horses from the Swedish island of Gotland. Mom's horse was a combination of Gotland and Thoroughbred. Dad's horse was a Tennessee walker.

We would go on family rides exploring our farm. Hot summer's day rides would always end in a run and jump off the dock into the cool lake water. There were cold spots in the lake where spring water rushed from beneath and finding them was always rewarding. It was off this dock that I discovered the art of pan-fishing. This involved a pan, a chunk of bread, and the skill to scoop up a fish as it came to the water's surface. I got good at this, and while on my own in my cowboy boots with spurs and sometimes nothing else, my dad would take Time-Life quality photos.

\section{Becoming a Cowboy}

When I was seven, I began working with my first horse, a pure-bred Tennessee Walker named Suzy. My dad had bought a mare, we had her bred, and I experienced the anticipation and wonder for the day my little horse would arrive. I cared and handled her for a couple of years until she was strong enough to saddle and ride. She was a very powerful and fast horse and, at times more than I could handle. I got bucked off often, and convinced, by my dad, to get back on until we trained (broke) that horse. My brother Chris helped out more than a time or two while I was healing. He would come in from a ride with my dad and say, 'man, that horse is turbocharged.'

\footnotetext{
${ }^{1}$ Corresponding author: Jemlindberg1965@gmail.com
} 
My father took our family on many extraordinary horse-riding adventures. Starting in Missouri and continuing to Colorado, these trips were epic. Dad had his Mercury Marquis retrofitted for airbags and a special reinforced trailer hitch attached directly to the car's frame. This enabled us to pull a horse trailer with a four-door family car. We drove that rig from Columbia, MO., over Independence Pass and the continental divide into Aspen, CO. During our journey, we would come to a ranch at night, and dad would unload the horses into someone's corral that he had arranged. The horses would rest, get water and food, and we would head off in the morning.

\section{Traveling}

The trips to Colorado, Oklahoma, and California made a big impression on me. Dad knew I loved riding as well as traveling. He had taken us to The Devil's Fork DudeRanch in Colorado, riding with Don King M.D. at King Ranch outside Aspen, as well as a well-organized ride on the Choctaw Nation Trail in the Ouachita Mountains of Oklahoma.

On the Indian Nations trail ride, I saw an amazing side of my dad that I had not witnessed before. I saw him learn some aspects of horse care in Colorado. When he later applied one lesson as an aid to some fellow riders, I realized that knowing something and conveying it to someone else were completely different things.

There were riders from many different states on the trail ride in Oklahoma, and some of their horses were not accustomed to drinking clear, fresh, snow meltwater. The result was the horse would refuse to drink. My dad showed some very concerned ridders that you could lead a horse to water, but sometimes the way to make him drink was to put some dirt in clean, clear water. So, from an ultimate communicator, I learned it's in the way the message is delivered....

\section{Influences}

Over the years, I would discover there were many interesting sides to my dad and so many proficiencies. We were all so fortunate to have learned from his example. There is no question that the things he taught me and the opportunities he and my mom made available shaped the way I am and the way I navigate the world. Photography, carpentry, powerboating, sailing, the art of putting on a successful social event are examples of skills he taught me. I have used a combination of these skills to become successful at various stages in my life. It is profound to think that my dad's influence on me was so strong. I continue to learn from his examples and lessons.

Growing up exposed to such good examples and diverse opportunities have made me realize my brothers and I had a fantastic childhood. We came of age under the guidance and influence of both our parents. It was said to me, by a good friend, that if he did not know my dad, he would have to conclude that none of my stories and experiences could have occurred or been true.

For example, I could not possibly have gone on a business trip to California with my dad to meet Ray Kroc (founder of McDonald's) at his horse ranch, select my horse and ride with him all afternoon in the mountains - where actual condors lived and hunted. I could not have spent a week with Ansel Adams, Bret Weston, Paul Caponigro, and 
other famous photographers attending a private course on Ansel's Carmel coast property. I most certainly could not have sailed in a trapeze position on a racing sailboat in the famous Viking town of Friesland, in the northern province of the Netherlands. Being taken by my dad to the dinner table of Dr. Albert Sabin (developer of the oral polio vaccine) at the Cosmos Club in Washington, D.C., for an introduction was a true honor. To watch my dad communicate with persons of intellect while possessing the facility to talk with the men that collected our trash was amazing. Watching dad build a darkroom out of empty space in our basement and later during dinner discuss the conversations he had with the President of the United States also was memorable.

In closing, the best story I have is when Donald A.B. Lindberg came to Washington State University to speak to the Neuroscience Department, where I hold a Research Assistant Position. Dr. Lindberg was very well received.

While these stories may seem boastful and outlandish, they are genuine examples of some of the gems that I have as memories of adventures with my dad. He grew up in Brooklyn, NY. Attended PS-197, Polytechnic Preparatory Country Day School, Amherst College, on to Columbia University College of Physicians and Surgeons - and the rest is history. I knew and will remember him as a visionary medical doctor, computer scientist, humanitarian but most importantly, a loving, caring, all-knowing, and consistent father. 